\title{
Beetroot (Beta vulgaris L.) Extract Ameliorates Gentamicin-Induced Nephrotoxicity Associated Oxidative Stress, Inflammation, and Apoptosis in Rodent Model
}

\author{
Ali A. El Gamal, ${ }^{1,2}$ Mansour S. AlSaid, ${ }^{1}$ Mohammad Raish, ${ }^{3}$ Mohammed Al-Sohaibani, \\ Shaza M. Al-Massarani, ${ }^{1}$ Ajaz Ahmad, ${ }^{5}$ Mohamed Hefnawy, ${ }^{6}$ Mohammed Al-Yahya, ${ }^{1}$ \\ Omer A. Basoudan, ${ }^{1}$ and Syed Rafatullah ${ }^{1}$ \\ ${ }^{1}$ Department of Pharmacognosy and Medicinal, Aromatic \& Poisonous Plants Research Center (MAPPRC), \\ College of Pharmacy, P.O. Box 2457, King Saud University, Riyadh 11451, Saudi Arabia \\ ${ }^{2}$ Department of Pharmacognosy, College of Pharmacy, Mansoura University, El Mansoura 35516, Egypt \\ ${ }^{3}$ Department of Pharmaceutics, College of Pharmacy, P.O. Box 2457, King Saud University, Riyadh 11451, Saudi Arabia \\ ${ }^{4}$ Department of Medicine and Pathology, Gastroenterology Unit, Collage of Medicine, King Khalid University Hospital, \\ King Saud University P.O., Box 2925, Riyadh 11461, Saudi Arabia \\ ${ }^{5}$ Department of Clinical Pharmacy, College of Pharmacy, P.O. Box 2457, King Saud University, Riyadh 11451, Saudi Arabia \\ ${ }^{6}$ Department of Pharmaceutical Chemistry, College of Pharmacy, P.O. Box 2457, King Saud University, Riyadh 11451, Saudi Arabia
}

Correspondence should be addressed to Mohammad Raish; mraish@ksu.edu.sa

Received 4 June 2014; Revised 11 September 2014; Accepted 29 September 2014; Published 22 October 2014

Academic Editor: Elaine Hatanaka

Copyright (C) 2014 Ali A. El Gamal et al. This is an open access article distributed under the Creative Commons Attribution License, which permits unrestricted use, distribution, and reproduction in any medium, provided the original work is properly cited.

\begin{abstract}
The present investigation was designed to investigate the protective effect of (Beta vulgaris L.) beat root ethanolic extract (BVEE) on gentamicin-induced nephrotoxicity and to elucidate the potential mechanism. Serum specific kidney function parameters (urea, uric acid, total protein, creatinine, and histopathology of kidney tissue) were evaluated to access gentamicin-induced nephrotoxicity. The oxidative/nitrosative stress (Lipid peroxidation, MDA, NP-SH, Catalase, and nitric oxide levels) was assessed. The inflammatory response (TNF- $\alpha$, IL-6, MPO, NF- $\kappa$ B (p65), and NF- $\kappa$ B (p65) DNA binding) and apoptotic marker (Caspase-3, Bax, and Bcl2) were also evaluated. BVEE ( 250 and $500 \mathrm{mg} / \mathrm{kg}$ ) treatment along with gentamicin restored/increased the renal endogenous antioxidant status. Gentamicin-induced increased renal inflammatory cytokines (TNF- $\alpha$ and IL-6), nuclear protein expression of NF- $\kappa \mathrm{B}$ (p65), NF- $\kappa \mathrm{B}-\mathrm{DNA}$ binding activity, myeloperoxidase (MPO) activity, and nitric oxide level were significantly down regulated upon BVEE treatment. In addition, BVEE treatment significantly reduced the amount of cleaved caspase 3 and Bax, protein expression and increased the Bcl-2 protein expression. BVEE treatment also ameliorated the extent of histologic injury and reduced inflammatory infiltration in renal tubules. These findings suggest that BVEE treatment attenuates renal dysfunction and structural damage through the reduction of oxidative stress, inflammation, and apoptosis in the kidney.
\end{abstract}

\section{Introduction}

The beetroot (Beta vulgaris L.), locally known as Shamandar, is a vegetable plant and belongs to family Amaranthaceae. The roots of beet have long been used in traditional Arab medicine to treat a wide variety of diseases. The claimed therapeutic use of beetroot includes its antitumor, carminative, emmenagogue, and hemostatic and renal protective properties and is a potential herb used in cardiovascular conditions [1]. Beetroot is known to be a powerful antioxidant [2]. In ancient times, beetroot was believed to help enhance human sex hormones and as an aphrodisiac. The juice of beetroot is also consumed as a natural remedy for sexual weakness and to expel kidney and bladder stones [3]. In recent years, beetroot has gained popularity to be a natural food to boost the energy in athletes $[4,5]$. The beetroot leaves were recommended by the Father of Medicine "Hippocrates" for faster healing of wounds [6]. Recent reports indicate 
that Beta vulgaris extracts (root) possess antihypertensive, hypoglycemic, antioxidant [7], anti-inflammatory, and hepatoprotective activities [6,8-10]. Previously, red beetroot extract has been demonstrated to be an effective multiorgan tumor suppressing agent in laboratory animals $[9,11,12]$.

Gentamicin (GM), an aminoglycoside, is known for its nephrotoxicity and one of the possible mechanisms suggested is damage due to generation of free radicals. [13, 14]. GM induces a dose-dependent nephrotoxicity in 10-25\% of therapeutic courses [15]. There are reports which suggest the role of ROS/Nitrogen species, in association with increased lipid peroxide formation and decreased activity of antioxidant enzymes in GM-induced nephrotoxicity [16]. Recent studies have also postulated that renal inflammation, which is characterized by infiltration of inflammatory cells such as monocytes/macrophages and subsequent release of proinflammatory cytokines and activation of NF- $\kappa \mathrm{B}$ in response to oxidative stress, is involved in this process $[17$, 18]. Furthermore, induced apoptosis/necrosis of renal tubular epithelial cells [19-21].

From above literature, Beta vulgaris is known to possess potent antioxidant, anti-inflammatory properties. Therefore, the present study was carried out to evaluate the renoprotective effect of Beta vulgaris ethanol extract (BVEE) against gentamicin induced nephrotoxicity in rats to substantiate its use in Arab traditional medicine.

\section{Materials and Methods}

2.1. Drugs and Chemicals. GM sulfate was obtained from Abbott Healthcare PVT Ltd, India. 2-thiobarbituric acid (TBA), antibodies against NF- $\kappa \mathrm{B}$ (p65), cleaved caspase-3, $\mathrm{Bax}, \mathrm{Bcl}-2, \beta$-actin, and HRP-conjugated secondary antibody were purchased from Santa Cruz biotech (USA). NE-PER nuclear and cytoplasmic extraction kit was obtained from Pierce Biotechnology, Rockford, IL, (USA). NF- $\kappa$ B (p65) transcription factor assay kit was obtained from Cayman Chemical Company, Ann Arbor, MI. Rat TNF- $\alpha$ and IL-6 ELISA kits were obtained from R\&D Systems, Inc. (USA). All other chemicals were of analytical grade.

2.2. Plant Material. The fresh beetroots were obtained from a local market in Riyadh. They were identified and authenticated by taxonomist Professor Mohammed Youssef, Department of Pharmacognosy, College of Pharmacy, King Saud University. A voucher specimen (number 0214) was deposited at the Herbarium of the College of Pharmacy, King Saud University, Riyadh, Saudi Arabia.

2.3. Preparation of the Extract and Fractions. The fresh roots of Beta vulgaris (1 kg, cut into small pieces) were exhaustively macerated by soaking in $70 \%(1.5 \mathrm{~L})$ ethanol and the process repeated for three successive days. The obtained alcoholic extract was then concentrated under reduced pressure using rotatory evaporator till complete drying. The resulted extract (BVEE, $150 \mathrm{~g}$ ) was later suspended in distilled water and evaluated for nephroprotective activity.
2.4. Scavenging Ability towards 2, 2-Diphenyl-1-picrylhydrazyl (DPPH) Radicals. The method was carried out as described by Brand-Williams et al., 1995 [22]. Various concentrations $(10,50,100,500$, and $1000 \mu \mathrm{g} / \mathrm{mL})$ of the crude extract and fractions were used. The assay mixtures contained in total volume of $1 \mathrm{~mL}, 500 \mu \mathrm{L}$ of the extract, $125 \mu \mathrm{L}$ prepared DPPH, and $375 \mu \mathrm{L}$ solvent. Ascorbic acid was used as the positive control. After $30 \mathrm{~min}$ incubation at $25^{\circ} \mathrm{C}$, the decrease in absorbance was measured at $\lambda=517 \mathrm{~nm}$. The radical scavenging activity was calculated from the following:

$$
\begin{aligned}
\text { \%radical scavenging activity }= & \left(\frac{\left(A_{\text {control }}-A_{\text {sample }}\right)}{A_{\text {control }}}\right) \\
& \times 100,
\end{aligned}
$$

where $A_{\text {sample }}$ and $A_{\text {control }}$ are absorbance of sample and control, respectively. The decrease in DPPH solution absorbance indicates an increase of DPPH radical scavenging activity of extract tested. The antioxidant activity was expressed as the number of equivalents of ascorbic acid.

2.5. Animals. Wistar albino rats, of either sex and approximately of same age (8-10 weeks), weighing 180-200 g was obtained from the Animal Care Center, College of Pharmacy, King Saud University, Riyadh, Saudi Arabia. Animals were kept at a constant temperature $\left(22 \pm 2^{\circ} \mathrm{C}\right)$, humidity (55\%), and light-dark conditions (12/12 h light/dark ratio). Animals were provided with Purina chow diet and drinking water $a d$ libitum. The protocol of the current study was approved by the Ethics Committee of the Experimental Animal Care Society, College of Pharmacy, King Saud University, Riyadh, Saudi Arabia.

2.6. Acute Toxicity Test. The acute toxicity test was performed on rats using oral route. Beet root extract was dissolved in distilled water and administered at various doses, ranging from 50 to $2000 \mathrm{mg} / \mathrm{kg}$ to the groups of rats. The animals were observed continuously for $1 \mathrm{~h}$ and then at half-hourly intervals for $4 \mathrm{~h}$ on the first day, for clinical signs and symptoms of toxicity further up to $72 \mathrm{~h}$ followed by 14 days for any mortality [23].

2.7. Experimental Design. Animals were divided into four groups (I, II, III, and IV) ( $n=6$ animals/group). Group I was kept as a control (no treatment). Groups II, II, and IV received gentamicin. GM was administered to group 2 in doses of $85 \mathrm{mg} / \mathrm{kg}$ body weight intraperitoneally (i.p.) daily for 8 days [24]. Groups 3 and 4 were treated with BVEE at the doses of 250 and $500 \mathrm{mg} / \mathrm{kg}$ weight (orally), respectively, for 20 days before GM treatment and there after concurrently with GM $(85 \mathrm{mg} / \mathrm{kg})$ for 8 days. The blood samples were collected after $24 \mathrm{~h}$ of last dose. The blood was collected and the serum was separated for biochemical estimations. After blood collection, the animals were sacrificed using ether anesthesia. The kidneys were dissected out and used for biochemical, molecular, and histopathological studies. 
2.8. Serum Analysis. Creatinine [25], uric acid [26], and urea [27] levels were estimated in serum using Reflotron Plus Analyzer and Roche Kits (Roche Diagnostics).

2.9. Determination of Malondialdehyde (MDA). The method reported by Utley et al., 1967 [28], was followed. The kidney tissues were removed and each tissue was homogenized in $0.15 \mathrm{M} \mathrm{KCl}$ (at $4^{\circ} \mathrm{C}$; Potter-Eivehjem type $\mathrm{C}$ homogenizer) to give a $10 \% \mathrm{w} / \mathrm{v}$ homogenate. Aliquots of homogenate $(1 \mathrm{~mL})$ were incubated at $37^{\circ} \mathrm{C}$ for $3 \mathrm{~h}$ in a metabolic shaker. Then $1 \mathrm{~mL}$ of $10 \%$ aqueous trichloroacetic acid was added and mixed. The mixture was then centrifuged at $800 \mathrm{~g}$ for $10 \mathrm{~min}$. $1 \mathrm{~mL}$ of the supernatant was removed and mixed with $1 \mathrm{~mL}$ of $0.67 \%$ thiobarbituric acid in water and placed in a boiling water bath for $10 \mathrm{~min}$. The mixture was cooled and diluted with $1 \mathrm{~mL}$ distilled water. The absorbance of the solution was then read at $535 \mathrm{~nm}$. The content of malondialdehyde $(\mathrm{nM} / \mathrm{g}$ wet tissue) was then calculated, by reference to a standard curve of malondialdehyde solution.

2.10. Estimation of Nonprotein Sulfhydryl's (NP-SH) Content in Kidney Tissue. Renal nonprotein sulfhydryl's was measured according to the method of Sedlak and Lindsay, 1968 [29]. The kidney was homogenized in ice-cold $0.02 \mathrm{mM} / \mathrm{L}$ ethylenediaminetetraacetic acid (EDTA). Aliquots of $5 \mathrm{~mL}$ of the homogenates were mixed in $15 \mathrm{~mL}$ test tubes with $4 \mathrm{~mL}$ of distilled water and $1 \mathrm{~mL}$ of $50 \%$ trichloroacetic acid (TCA). The tubes were shaken intermittently for $10 \mathrm{~min}$ and centrifuged at $3000 \mathrm{rpm}$ for $10 \mathrm{~min}$. Two milliliters of supernatant was mixed with $4 \mathrm{~mL}$ Tris buffer $(0.4 \mathrm{~mol} / \mathrm{L})(\mathrm{pH}$ 8.9). $0.1 \mathrm{~mL}$ of $5,5^{\prime}$-dithiobis(2-nitrobenzoic acid) (DTNB) was added and the sample was shaken. The absorbance was measured within $5 \mathrm{~min}$ of addition of DTNB at $412 \mathrm{~nm}$ against a reagent blank. The content of NPSH was calculated using spectrophotometer.

2.11. Estimation of Catalase and Total Protein Content of Kidney Tissue. The catalase was estimated by the kit method, supplied by Crescent Diagnostics, Jeddah, Saudi Arabia.

2.12. Myeloperoxidase (MPO) Level of Kidney Tissue. MPO assay neutrophil recruitment was indirectly measured by means of MPO activity, determined according to the method described previously by Krueger et al. 1990 [30]. Samples were homogenized at $5 \%(\mathrm{w} / \mathrm{v})$ in EDTA/NaCl buffer $(\mathrm{pH} 4.7)$ and centrifuged at $10,000 \mathrm{rpm}$ for $15 \mathrm{~min}$ at $4^{\circ} \mathrm{C}$. The pellet was resuspended in $0.5 \%$ hexadecyl-trimethyl ammonium bromide buffer ( $\mathrm{pH}$ 5.4), and the samples were frozen and thawed three times in liquid nitrogen. Upon thawing, the samples were recentrifuged $\left(10,000 \mathrm{rpm}, 15 \mathrm{~min}, 4^{\circ} \mathrm{C}\right)$, and $25 \mu \mathrm{L}$ of the supernatant was used for the MPO assay. The enzymatic reaction was assessed with $1.6 \mathrm{mM}$ tetramethylbenzidine, $80 \mathrm{mM} \mathrm{NaPO}_{4}$, and $0.3 \mathrm{mM}$ hydrogen peroxide. The absorbance was measured at $690 \mathrm{~nm}$, and the results were expressed as optical density per $\mathrm{mg}$ of tissue.

2.13. Proinflammatory Cytokine Determination. TNF- $\alpha$ and IL-6 concentrations in the kidney tissue samples were estimated using commercially available kits from R\&D Systems, USA. The principle of assay was sandwich ELISA. Absorbance was taken at $450 \mathrm{~nm}$. The protein level of supernatant was estimated and the TNF- $\alpha$ and IL- 6 levels were expressed as $\mathrm{pg} / \mathrm{mg}$ of protein.

2.14. Assessment of Nitric Oxide. In the assay, nitrate was converted to nitrite by nitrate reductase and total nitrite was measured using the Griess reaction [31]. Briefly, samples were incubated with nitrate reductase $(0.2 \mathrm{U} / \mathrm{mL})$, FAD $(5 \mathrm{mM})$, and NADPH $(50 \mathrm{mM})$ for 20 minutes at $37^{\circ} \mathrm{C}$. The reaction was stopped by addition of sodium pyruvate $(10 \mathrm{mM})$ and lactate dehydrogenase $(24 \mathrm{mg} / \mathrm{mL})$ for five minutes at $37^{\circ} \mathrm{C}$ and precipitated with $1.4 \% \mathrm{ZnSO}_{4}$. Total nitrite reacted with Griess reagent ( $1 \%$ sulphanilamide, $2.5 \% \mathrm{PO}_{4} \mathrm{H}_{3}, 0.1 \% \mathrm{n}$ naphthylethylenediamine) for 10 minutes at $37^{\circ} \mathrm{C}$ and was read using the $540 \mathrm{~nm}$ filter in a titrated Biotek ELISA reader.

2.15. Preparation of Nuclear and Total Protein Extracts. Frozen kidney tissue from different experimental groups was homogenized in ice-cold RIPA buffer containing $1 \%$ protease inhibitor cocktail (Sigma-Aldrich) to get total protein extracts. After being centrifuged at $2500 \times \mathrm{g}$ for $20 \mathrm{~min}$ at $4^{\circ} \mathrm{C}$, the supernatant was collected and used for analysis of cleaved caspase-3, Bax, Bci-2, and $\beta$-actin expression. Similarly, nuclear extracts were prepared by using NE-PER nuclear and cytoplasmic extraction kit (Pierce Biotechnology, Rockford, IL, USA) containing $1 \%$ protease inhibitor cocktail (Sigma-Aldrich) according to the manufacturer's protocol and used for analysis of NF- $\kappa \mathrm{B}$ (p65) protein expression as well as NF- $\kappa \mathrm{B}-\mathrm{DNA}$ binding assay. The protein contents were determined by using Lowry method against a standard curve of a selected standard protein solution bovine serum albumin (BSA).

2.16. Analysis of NF- $\kappa B$ (p65) Activation by ELISA. NF$\kappa \mathrm{B}$ DNA-binding activity was analyzed using the NF- $\kappa \mathrm{B}$ (p65) transcription factor ELISA assay kit Cayman Chemical Company, Ann Arbor, (USA). Briefly, nuclear extracts were incubated in the oligonucleotide-coated wells where the oligonucleotide sequence contains the NF- $\kappa \mathrm{B}$ response element consensus-binding site. After washing, samples were incubated by addition of specific primary antibody directed against NF- $\kappa$ B (p65). A secondary antibody conjugated to horseradish peroxidase (HRP) was added to provide a sensitive colorimetric readout at $450 \mathrm{~nm}$.

2.17. Western Blot Analysis. Western blot analysis was performed according to Towbin et al. [32]. The proteins were electrophoretically transferred to PVDF membranes, blocked in 5\% skim milk in Tris buffer saline (TBS) containing $1 \%$ Tween 20 for $2 \mathrm{hr}$ at room temperature and probed with the polyclonal cleaved caspase-3 (sc-22171-R), Bax (sc6236), Bcl-2 (sc-492), and NF- $\kappa$ B (p65) (sc-398442) and $\beta$-actin (sc-47778) polyclonal rabbit-anti rat antibodies as solutions in PBS containing 1\% Tween 20 on a shaker for $2 \mathrm{hr}$ at room temperature followed by horseradish peroxidase(HRP-) conjugated secondary antibodies $(1: 3000)$ for $1 \mathrm{~h}$ and 
TABLE 1: Free radical-scavenging activity of the BVEE, fractions, and ascorbic acid (DPPH-assay).

\begin{tabular}{lccccc}
\hline \multirow{2}{*}{ Treatment } & \multicolumn{4}{c}{ Radical scavenging activity (\%) } \\
& $10 \mu \mathrm{g} / \mathrm{mL}$ & $50 \mu \mathrm{g} / \mathrm{mL}$ & $100 \mu \mathrm{g} / \mathrm{mL}$ & $500 \mu \mathrm{g} / \mathrm{mL}$ & 90.1 \\
BVEE & 25.0 & 27.0 & 38.4 & 90.9 & 98.1 \\
Ascorbic acid (STD) & 41.0 & 86.4 & 95.5 & 98.3 \\
\hline
\end{tabular}

TABLE 2: Effect of BVEE on nephrotoxicity markers in serum.

\begin{tabular}{lccccc}
\hline Treatment & Dose $(\mathrm{mg} / \mathrm{kg})$ & $\begin{array}{c}\text { Urea } \\
(\mathrm{nM} / \mathrm{L})\end{array}$ & $\begin{array}{c}\text { Uric acid } \\
(\mathrm{mg} / \mathrm{dL})\end{array}$ & $\begin{array}{c}\text { Protein } \\
(\mathrm{g} / \mathrm{dL})\end{array}$ & $\begin{array}{c}\text { Creatinine } \\
(\mathrm{mg} / \mathrm{dL})\end{array}$ \\
\hline Normal (control) & - & $28.50 \pm 1.17$ & $1.11 \pm 0.14$ & $8.23 \pm 0.14$ & $2.12 \pm 0.26$ \\
Gentamicin & 85 & $137.00 \pm 5.87^{* * * \mathrm{a}}$ & $5.36 \pm 0.34^{* * * \mathrm{a}}$ & $3.82 \pm 0.23^{* * * \mathrm{a}}$ & $9.25 \pm 0.46^{* * * \mathrm{a}}$ \\
BVEE + gentamicin & 250 & $120.83 \pm 4.40^{* \mathrm{~b}}$ & $4.19 \pm 0.32^{* \mathrm{~b}}$ & $4.98 \pm 0.36^{* \mathrm{~b}}$ & $7.12 \pm 0.59^{* \mathrm{~b}}$ \\
BVEE + gentamicin & 500 & $80.31 \pm 4.63^{* * * \mathrm{~b}}$ & $2.77 \pm 0.21^{* * * \mathrm{~b}}$ & $6.37 \pm 0.50^{* * \mathrm{~b}}$ & $4.90 \pm 0.33^{* * * \mathrm{~b}}$ \\
\hline
\end{tabular}

All values represent mean \pm SEM. ${ }^{*} P<0.05,{ }^{* *} P<0.01,{ }^{* * *} P<0.001 ;{ }^{\mathrm{a}} P<0.05,{ }^{\mathrm{b}} P<0.01,{ }^{\mathrm{c}} P<0.001$. ANOVA, followed by Dunnett's test.

${ }^{*, * *, * * *}$ As compared with normal group. ${ }^{\mathrm{a}, \mathrm{b}, \mathrm{c}}$ As compared with GM only group.

visualization with the enhanced chemiluminescence system Santa Cruz Biotechnology (USA). $\beta$-actin was used as the loading control for total proteins densitometric analysis of immunoblots was performed with the Image J software (NIH).

2.18. Statistical Analysis. Values are given as arithmetic means \pm standard error of the mean (SEM). Data were statistically analyzed by using one-way analysis of variance (ANOVA) followed by Dennett's test.

\section{Results}

3.1. DPPH Free Radical Scavenging Activity. The ethanolic extract of $B$. vulgaris (BVEE) and fractions were tested for their in vitro antioxidant activity using $\mathrm{DPPH}$ radical scavenging assay method with ascorbic acid as a reference. The obtained results are presented in Table 1 . The radical scavenging activity of the BVEE showed highest activity (90.9\%) at concentrations 500 and $1000 \mu \mathrm{g} / \mathrm{mL}$, respectively, comparing to ascorbic acid.

3.2. Effect of BVEE on Kidney Function Tests. The effect of BVEE treatment on the GM-induced nephrotoxicity on urea, uric acid, total protein, and creatinine levels in serum are shown in Table 2. Administration of GM significantly elevated the levels of urea $(28.50 \pm 1.17$ to $137.00 \pm 5.87 \mathrm{nM} / \mathrm{L}$, $P<0.001)$, uric acid $(1.11 \pm 0.14$ to $5.36 \pm 0.34 \mathrm{mg} / \mathrm{dL}$, $P<0.001)$, total protein $(3.82 \pm 0.23$ to $8.23 \pm 0.14, P<$ $0.001)$, and creatinine $(2.12 \pm 0.26$ to $9.25 \pm 0.46 \mathrm{mg} / \mathrm{dL}, P<$ 0.001 ), in serum. Treatment of rats with the BVEE (250 and $500 \mathrm{mg} / \mathrm{kg}$ p.o) significantly prevented the elevation of urea, uric acid, total protein, and creatinine levels in serum in dose dependent manner.

3.3. Effect of BVEE on the Level of MDA in GM-Induced Renal Damage. The extent of lipid peroxidation as measured by formation of (MDA) as depicted in Figure 1(a). There is a sharp increase in (MDA) level in GM treated (Group II) rats
$(1.28 \pm 0.08$ to $7.91 \pm 0.67)$ indicative of oxidative stress. The BVEE $250 \mathrm{mg} / \mathrm{kg}$ and $500 \mathrm{mg} / \mathrm{kg}+\mathrm{GM}$ groups III and IV treated rats showed significant dose dependent reduction of MDA level as compared to GM (group II) treated rat. This clearly showed the dose dependent reduction oxidative stress in terms of MDA content by BVEE (250 and $500 \mathrm{mg} / \mathrm{kg}$ p.o) $37.54 \%$ (4.94 $\pm 0.44 \mathrm{nM} / \mathrm{mg}$ tissue $P<0.01$ ), and $58.28 \%$ (3.3 $\pm 0.44 \mathrm{nM} / \mathrm{mg}$ tissue), respectively, as compared to GM treated rat in group II $(7.91 \pm 0.67 \mathrm{nM} / \mathrm{mg}$ tissue, $P<0.01)$.

3.4. Effect of BVEE on the Level of Reduced NP-SH Content in GM-Induced Renal Damage. GM $85 \mathrm{mg} / \mathrm{kg}$ treatment rats to group II showed significant decrease in NP-SH content $37.94 \%$ (6.64 \pm 0.18 to $2.52 \pm 0.35, P<0.001)$ indicative increase in protein metabolism, whereas there is a significant dose dependent increase in NP-SH content in group III pretreated with BVEE $250 \mathrm{mg} / \mathrm{kg}+\mathrm{GM} 85 \mathrm{mg} / \mathrm{kg} 71 \%$ (6.64 to $4.77 \pm 0.43, P<0.01)$ and group IV pretreated with BVEE $500 \mathrm{mg} / \mathrm{kg}+\mathrm{GM}$ treated groups $81.71 \%$ (6.64 \pm 0.18 to $5.43 \pm 0.38, P<0.001)$ in comparison to GM treated group II. This clearly indicates that BVEE 250 and $500 \mathrm{mg} / \mathrm{kg}$ have ability to replenish the NP-SH content to normal levels as shown in Figure 1(b).

3.5. Effect of BVEE on Catalase Activity in GM-Induced Renal Damage. GM treatment caused $27.97 \%$ significant decrease in catalase activity $(11.26 \pm 0.997$ to $8.11 \pm 0.040 \mathrm{U} / \mathrm{L}, P<$ 0.01 ), in group II rats as compared to normal control kidney tissue (Figure $1(\mathrm{c})$ ). The pretreatment of BVEE at the doses of 250 and $500 \mathrm{mg} / \mathrm{kg}$ resulted in a significant increase of catalase level from $(8.11 \pm 0.040$ to $9.45 \pm 0.032 \mathrm{U} / \mathrm{L}$ and $10.43 \pm 0.191, P<0.01)$ as compared to group II: therefore, BVEE has ability to replenished the catalase level significantly in dose dependent manner which is about $83.92 \%$ and $92.62 \%$ for BVEE 250 and $500 \mathrm{mg} / \mathrm{kg}$, respectively.

3.6. Effect of BVEE on the Level of Total Protein in GMInduced Renal Damage. As depicted in Figure 1(d), GM treated rats group II showed significant decrease in total 


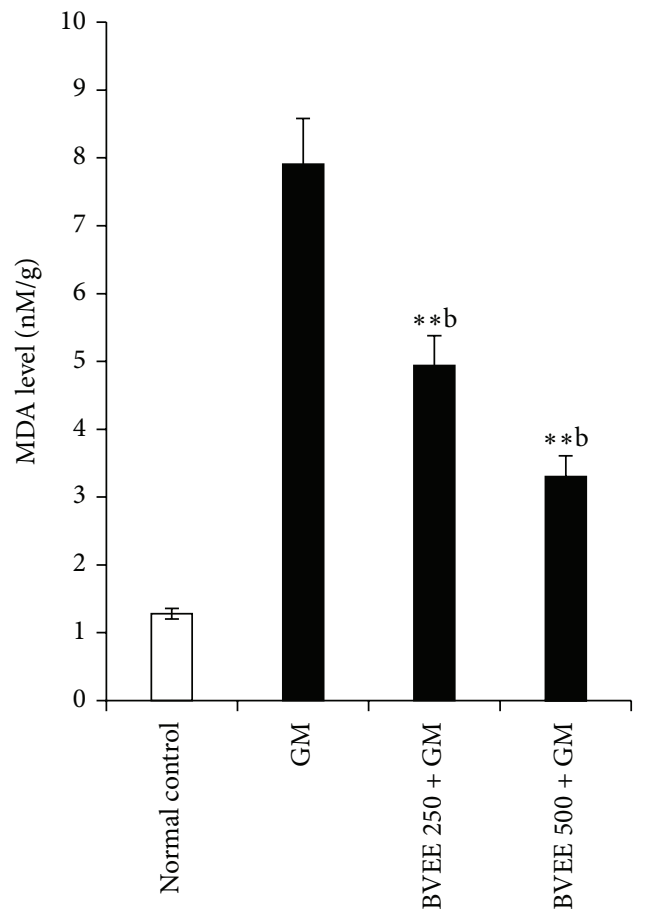

(a)

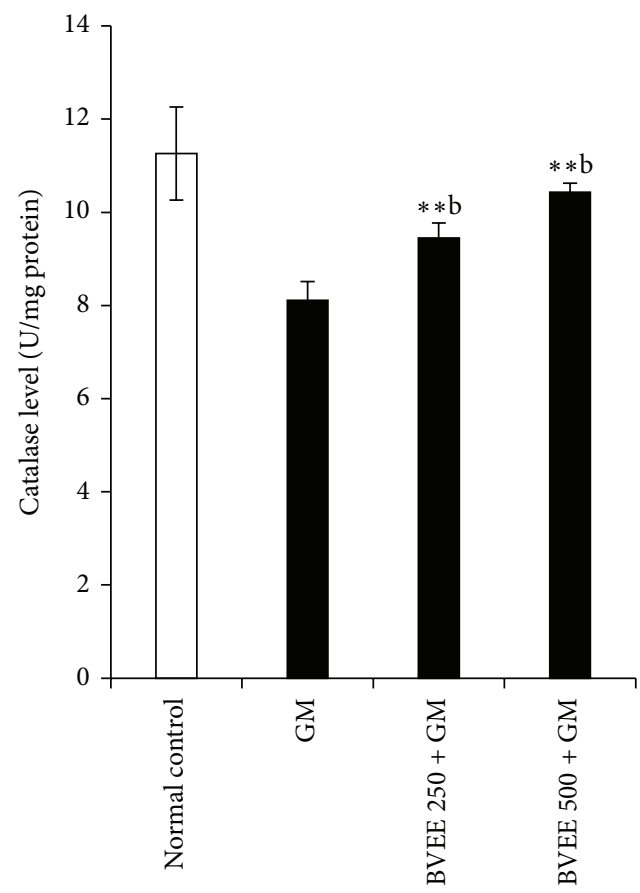

(c)

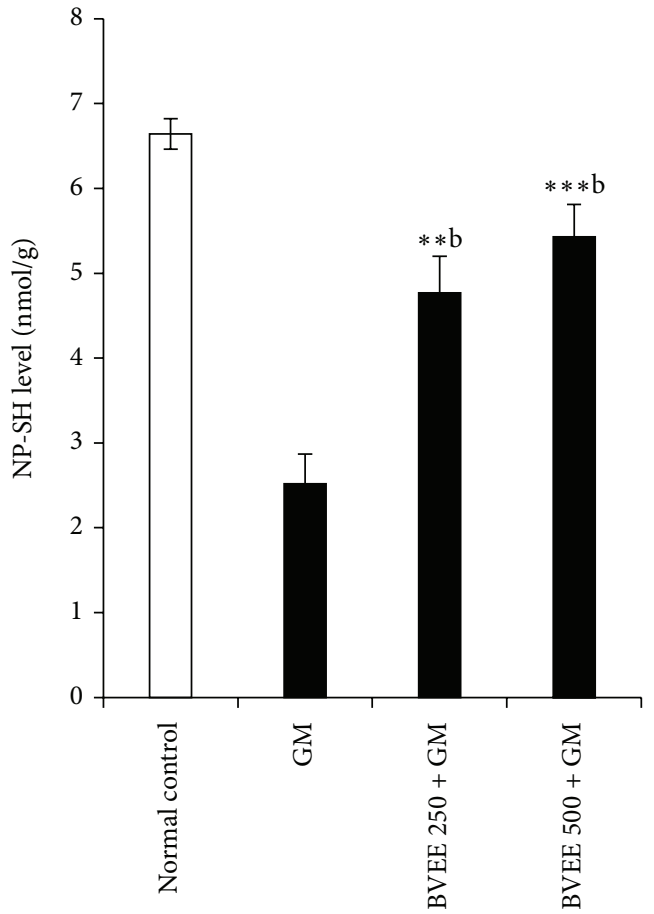

(b)

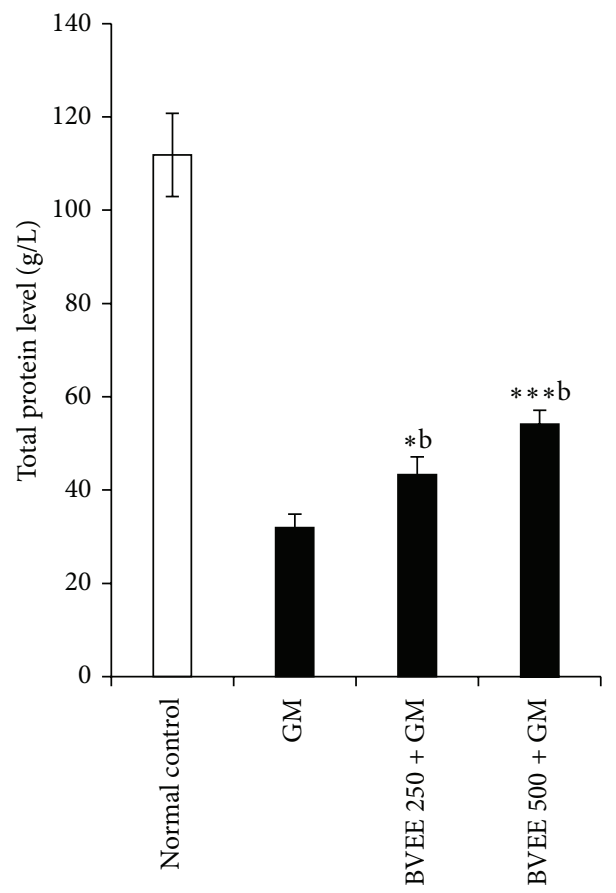

(d)

FIGURE 1: Effect of BVEE (250 and $500 \mathrm{mg} / \mathrm{kg}$; p.o) on gentamicin induced nephrotoxicity on kidney lipid peroxidation: (a) MDA; (b) NP$\mathrm{SH}$; (c) catalase activity; and (d) total protein. The results are presented as the mean \pm SEM. of six animals per group. “*, $* *$ ” $* * *$ denotes significant differences from the control group $(P<0.05, P<0.01$, and $P<0.001)$; “a,b, " denote significant differences from the GM group $(P<0.05, P<0.01$, and $P<0.001)$. 


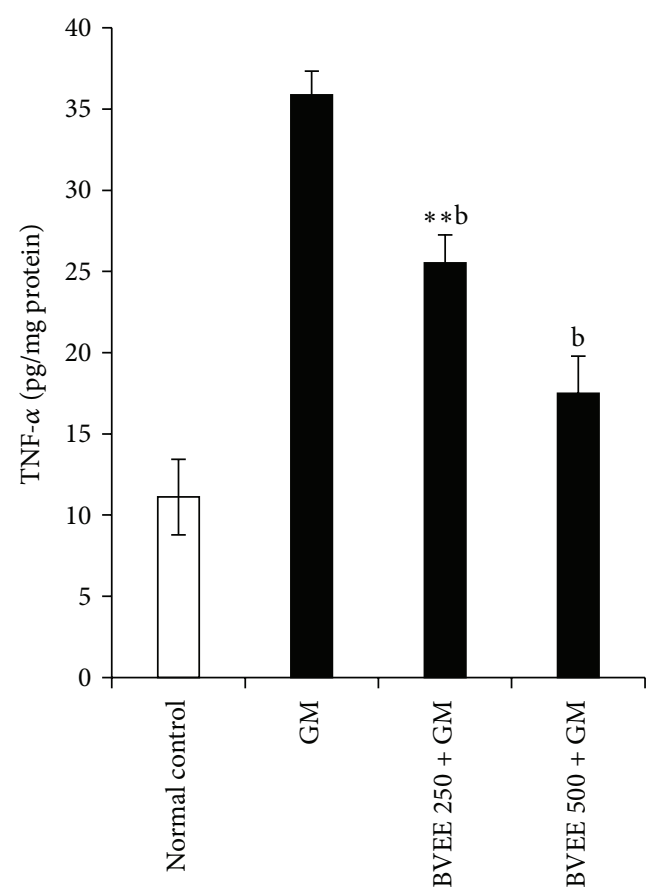

(a)

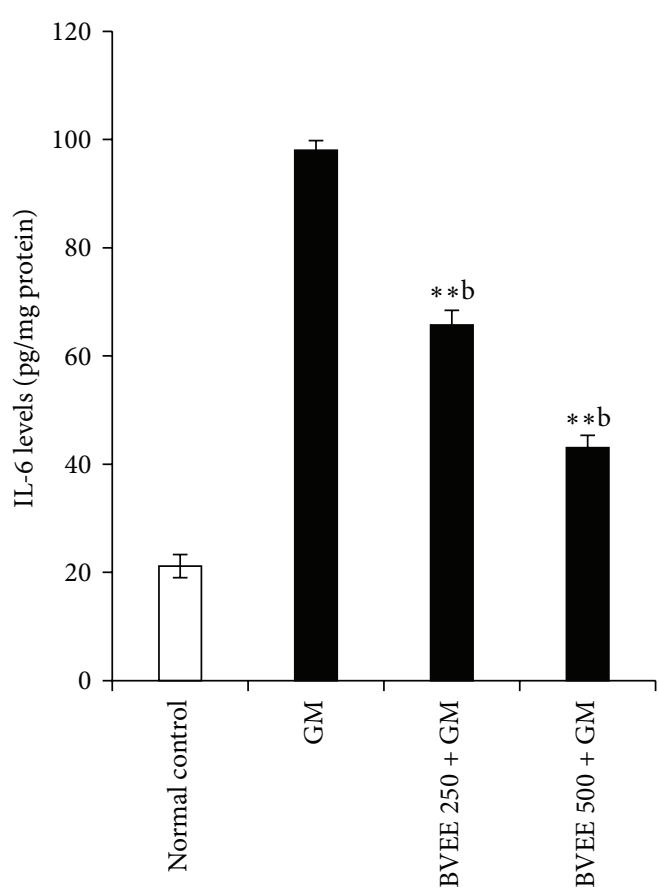

(b)

FIGURE 2: Effect of BVEE on gentamicin-induced changes in proinflammatory cytokines in kidney tissues of rats. (a) Tumor necrosis factor- $\alpha$ (TNF- $\alpha$ ) and (b) interleukin-6 (IL-6). The results are presented as the mean \pm SEM of six animals per group. “*, **” *** denotes significant differences from the control group $(P<0.05, P<0.01$, and $P<0.001)$; “a,b, c” denote significant differences from the GM group $(P<0.05$, $P<0.01$, and $P<0.001)$.

protein, $71.46 \%$ (from $111.85 \pm 8.93$ to $31.92 \pm 2.89 \mathrm{~g} / \mathrm{L}$, $P<0.01$ ), content which is indicative of GM-induced kidney injuries caused due to oxidative stress, whereas there is a dose dependent increase in total protein content significantly in group III pretreated with BVEE $250 \mathrm{mg} / \mathrm{kg}+\mathrm{GM}$ and group IV pretreated with BVEE $500 \mathrm{mg} / \mathrm{kg}+\mathrm{GM}$ treated groups in comparison with group III which is about $37.35 \%$ $(43.27 \pm 3.85 \mathrm{U} / \mathrm{L}, P<0.01)$ and $43.74 \%(54.15 \pm 2.97 \mathrm{U} / \mathrm{L}$, $P<0.001)$. This clearly indicates that BVEE has ability to induce cell proliferation.

3.7. Effect of BVEE on Proinflammatory Cytokine (TNF- $\alpha$ and IL-6) in GM-Induced Renal Damage. As depicted in Figure 2, GM administration produced a significant 3.2-fold elevation of TNF- $\alpha(11.11 \pm 2.322$ to $35.88 \pm 1.4, P<0.001)$ and 4.63 fold elevation of IL- $6(21.13 \pm 2.14$ to $98 \pm 1.77)$ (Figure $2(\mathrm{a})$ ) levels when compared to group I control rats. BVEE treatment $(250$ and $500 \mathrm{mg} / \mathrm{kg})$ along with GM significantly $(P<$ $0.01)$ decreased the TNF- $\alpha$ levels by 1.4 -fold from $(35.88 \pm 1.4$ to $25.54 \pm 1.45)$ when compared with GM control. However, IL-6 levels were significantly $(P<0.01)$ decreased in BVEE treatment at both doses $(250 \mathrm{mg} / \mathrm{kg}$ and $500 \mathrm{mg} / \mathrm{kg})$ from $98 \pm 1.77$ to $65.74 \pm 2.64, P<0.01$, and $98 \pm 1.77$ to $43.06 \pm 2.25$, $P<0.01$. compared to group II GM alone treated rats (Figure 2(b)). These results show that BVEE downregulate the IL-6 level and hence have potent anti-inflammatory activity.

3.8. Effect of BVEE on Myeloperoxidase (MPO) Activity and Nitrous Oxide Level in GM-Induced Renal Damage. As depicted in Figure 3(a), Myeloperoxidase (MPO) activity was significantly $(16.71 \pm 0.97$ to $30.21 \pm 0.83, P<0.01)$ increased in the kidney tissues of GM alone treated rats when compared to control rats. BVEE decreased the Myeloperoxidase (MPO) activity significantly $(18.39 \pm 0.63, P<0.01$, at $250 \mathrm{mg} / \mathrm{kg}$ group III and $15.04 \pm 0.74, P<0.01$, at $500 \mathrm{mg} / \mathrm{kg}$ BVEE group IV) plus GM treated rats in comparison with group II GM treated rats. These results demonstrate the antiinflammatory potential of BVEE.

To examine the involvement of nitric oxide in the protection against GM-induced renal injury by BVEE; we determined renal nitric oxide levels. As depicted in Figure 3(b) GM treated rats group II showed significant increase in nitric oxide level $43.4 \%$ (from $31.85 \pm 1.10$ to $45.68 \pm 1.65 \mathrm{nM} / \mathrm{mg}$ protein, $P<0.01$ ) content which is indicative of GM-induced kidney injuries caused due to oxidative stress. Whereas, there is a dose dependent decrease in nitric oxide content significantly in group III pretreated with BVEE $250 \mathrm{mg} / \mathrm{kg}+$ GM and group IV pretreated with BVEE $500 \mathrm{mg} / \mathrm{kg}+\mathrm{GM}$ treated groups in comparison with group II which is about $18.38 \%(37.28 \pm 1.19 \mathrm{nM} / \mathrm{mg}$ protein, $P<0.05)$ and $25.42 \%$ $(34.07 \pm 0.67 \mathrm{nM} / \mathrm{mg}$ protein, $P<0.01)$. This clearly indicates that BVEE inhibits the nitric oxide significantly; hence it has anti-inflammatory properties.

3.9. Effect of BVEE on NF- $\kappa B$ in GM-Induced Renal Damage and Apoptosis. As illustrated in Figure 4(a), GM significantly increased the nuclear translocation of p65 subunit of NF- $\kappa \mathrm{B}$ and NF- $\kappa$ B-DNA binding activity (Figure $4(\mathrm{~b})$ ) compared to 


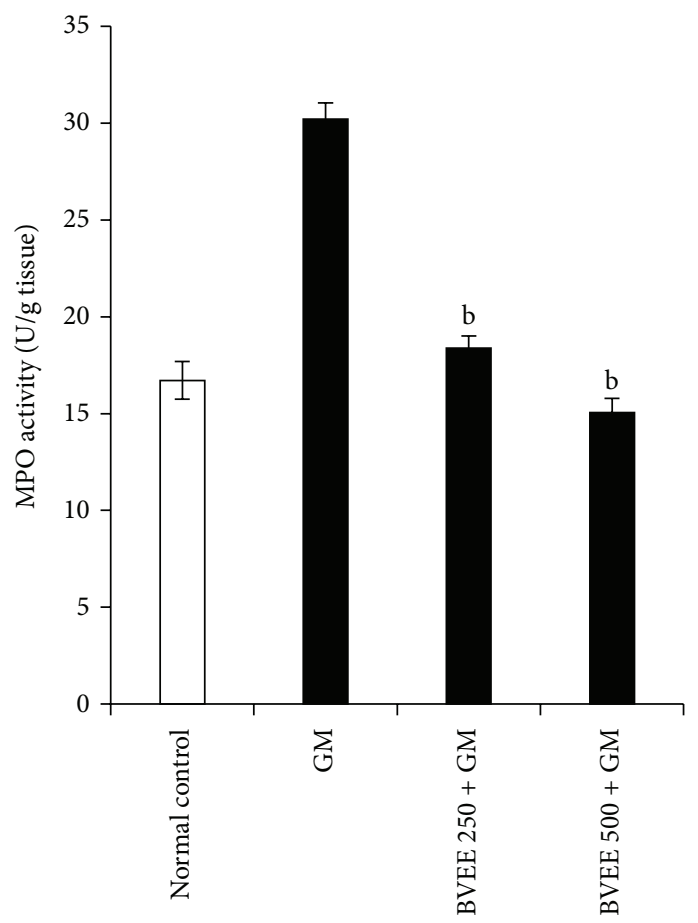

(a)

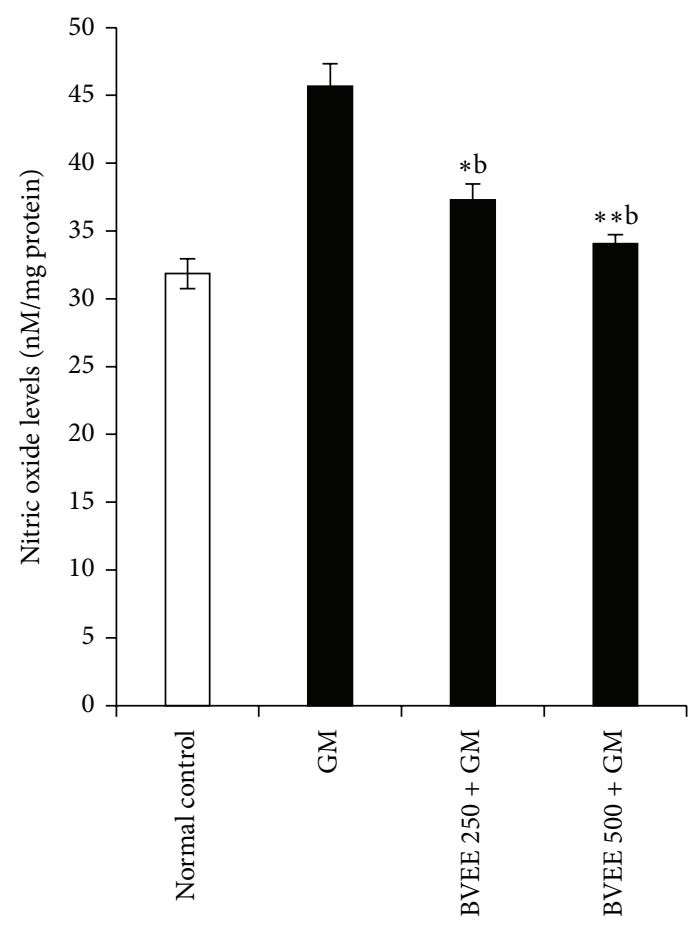

(b)

FIGURE 3: Effect of BVEE on gentamicin-induced changes in inflammatory markers in kidney tissues of rats. (a) Myeloperoxidase (MPO) and (b) nitric oxide $(\mathrm{NO})$. The results are presented as the mean \pm SEM of six animals per group. “*, **” *** denotes significant differences from the control group $(P<0.05, P<0.01$, and $P<0.001)$; “a,b, c" denote significant differences from the GM group $(P<0.05, P<0.01$, and $P<0.001)$.

vehicle control rats. BVEE treatment at 250 and $500 \mathrm{mg} / \mathrm{kg}$ significantly reduced both nuclear NF- $\kappa \mathrm{B}$ (p65) protein expression and DNA-binding activity when compared to GM alone treated rats. GM administration significantly elevates the renal protein expression of Bax and cleaved caspase 3 activities and significantly $(P<0.01)$ downregulates the Bcl2 protein expression when compared to vehicle control rats as shown in Figure 4(c).

3.10. Histopathological Assessment. Treatment of rats with GM showed a focal interstitial nephritis made up of lymphocytes and plasma cells with desquamation of renal tubules epithelium and vacuolization. Simultaneous treatment of GM-induced nephrotoxic rats with BVEE high dose maintained almost normal tubules, interstitial nephritis, and glomeruli (Figure 5).

\section{Discussion}

Gentamicin is an aminoglycoside antibiotic used against the sepsis in human, but it causes acute renal failure in $10-15 \%$ of the patients [33], while more than $30 \%$ of the patients showed the signs of nephrotoxicity which have received the gentamicin for more than 7 days [34]. However, due to the selective accumulation of GM in renal cortex [35] leading to nephrotoxicity, its use has been restricted. GM-induced nephrotoxicity causes significant increase in the serum level of kidney function markers such as creatinine, urea, and uric acid as compared to respective control indicating renal dysfunction [36-39]. Administration of BVEE along with gentamicin caused significant decrease in the concentration of creatinine, Urea, and uric acid, while a significant increase in total protein of serum suggested the protective effects of BVEE. Similar protective studies of different extracts against gentamicin have been reported previously $[36,40]$. Treatment of GM causes significant increase in the serum level of kidney function markers such as creatinine, Urea, and uric acid as compared to respective control indicating renal dysfunction. As the serum creatinine, urea and uric acid are the ultimate metabolites of purine which may alter the glomerular filtration rate and lead to enhancing their levels in serum and associated with renal damage [41]. Several report suggesting a possible role of oxidative stress in gentamicininduced kidney dysfunction $[36,42]$. Depletion in the CAT, TP, and NP-SH after GM exposure has been reported in other studies suggesting that oxidative stress is one of the causes of renal injuries induced with GM toxicity in rats [43]. Several studies indicate that antioxidant enzymes, including NP-SH and CAT, are inactivated by ROS, including superoxide anion radical and hydrogen peroxide $[44,45]$.

MDA is an end product of LPO. In this study, an increased level of MDA concentration which is an important pathogenic factor(s) that injures biomembranes was observed [46]. Treatment of BVEE to rats in combination with gentamicin reversed all these alterations suggesting that BVEE rendered its antioxidant properties by preventing or 


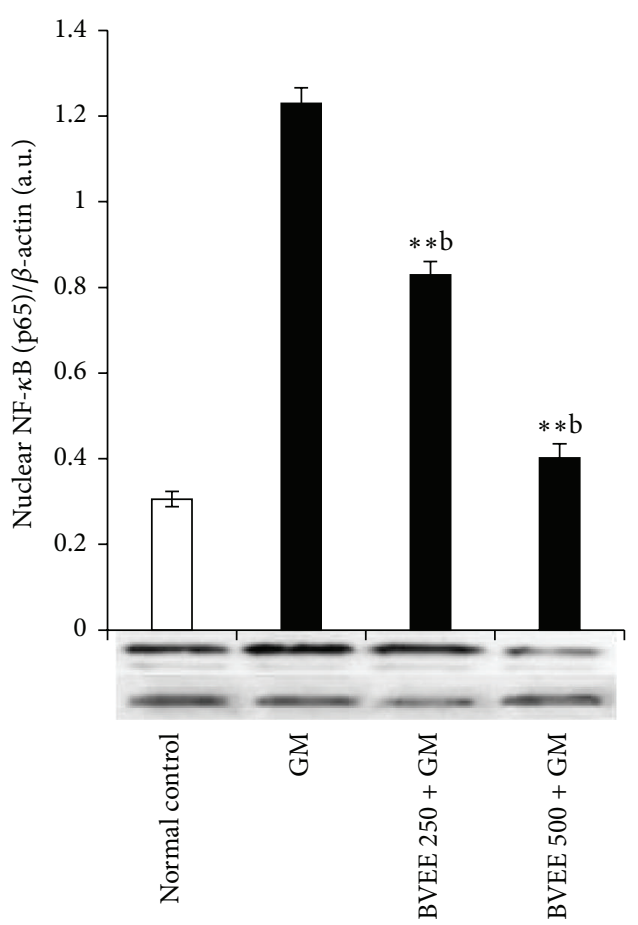

(a)

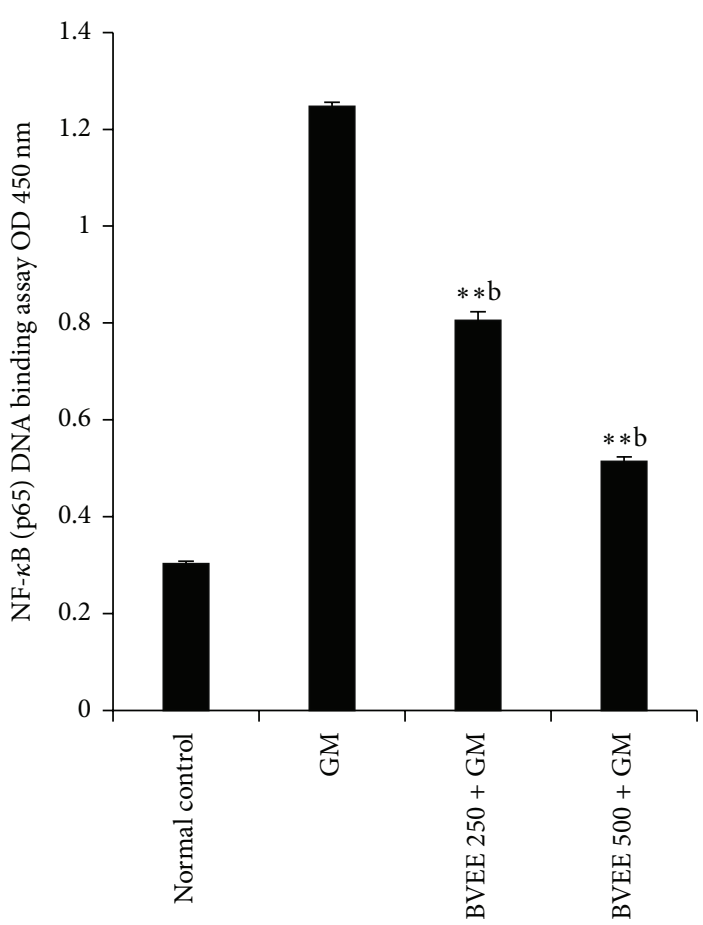

(b)

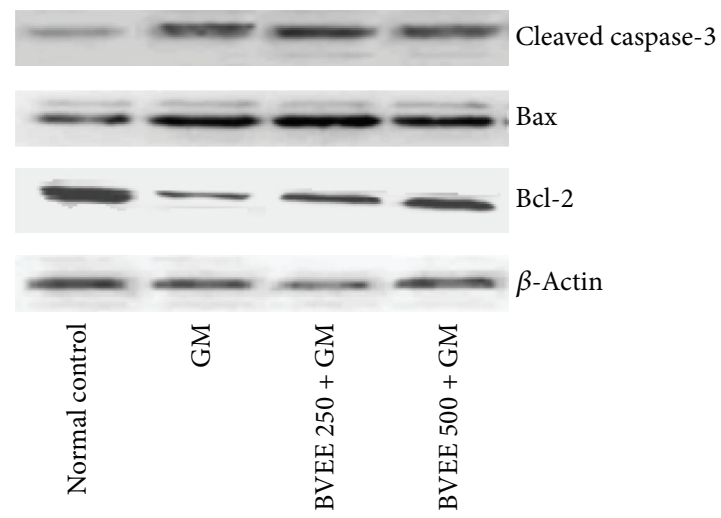

(c)

FIGURE 4: Effect of BVEE on gentamicin-induced changes in inflammatory and apoptotic markers in kidney tissues of rats. (a) Immunoblots analysis of nuclear NF- $\kappa \mathrm{B}$ (p65) expression in the kidney tissue of rats treated with BVEE and/or gentamicin. B-Actin expression was used as a loading control. Representative bar diagram showing quantitative relative levels of NF- $\kappa \mathrm{B}$ (p65) protein for vehicle, GM, and GM and BVEE treated rats. (b) Nuclear NF- $\kappa$ B (p65) DNA-binding activity determined by using NF- $\kappa$ B (p65) transcription factor ELISA assay kit. (c) Immunoblot analysis of apoptotic marker cleaved caspase-3 and Bax protein and antiapoptotic marker Bcl-2 protein in comparison with $\mathrm{B}$-actin expression was used as a loading control. The results are presented as the mean \pm SEM of six animals per group. “*, $* *$ ” *** denotes significant differences from the control group $(P<0.05, P<0.01$, and $P<0.001)$; “a,b,c” denote significant differences from the GM group $(P<0.05, P<0.01$, and $P<0.001)$.

scavenging the ROS induced with GM toxicity. Antioxidants like Vitamin $\mathrm{C}$ and $\mathrm{E}$ were commonly used to reduce the GM-induced nephrotoxicity $[47,48]$. In recent years efforts are focused on the development of antioxidants from natural sources including, herbs, vegetables, and fruits which are able to minimize the toxic effects of GM on kidney $[13,49]$. Our results are in accord with other studies where antioxidant effects of other plants have been reported against gentamicin induced renal damage $[50,51]$. There are several reports which suggest that beet root extract has beet pigment known as betalains. The betalains found in beetroot were vulgaxanthin I, vulgaxanthin II, indicaxanthin, betanin, prebetanin, isobetanin, and neobetanin. Also cyclodopa glucoside, $\mathrm{N}$ formylcyclodopa glucoside, glucoside of dihydroxyindole carboxylic acid, betalamic acid, l-tryptophan, $p$-coumaric acid, ferulic acid, and traces of unidentified flavonoids were detected $[10,52]$, in addition to the pigments, the root contains oxalic acid, and ascorbic acid. Our findings in in vitro antioxidant assay (DPPH) showed a potent antioxidant activity, which further supports its radical scavenging 


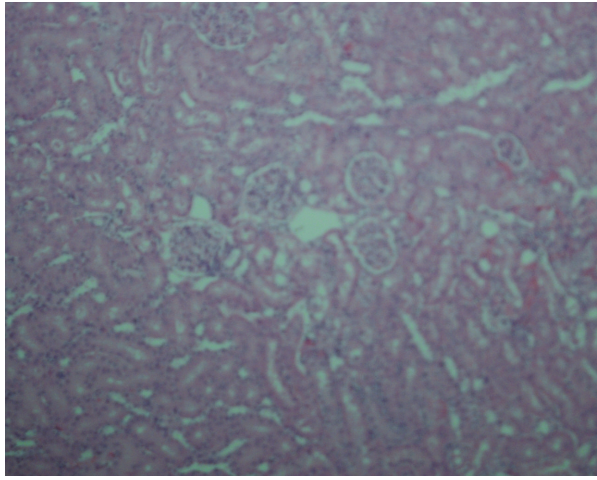

(a)

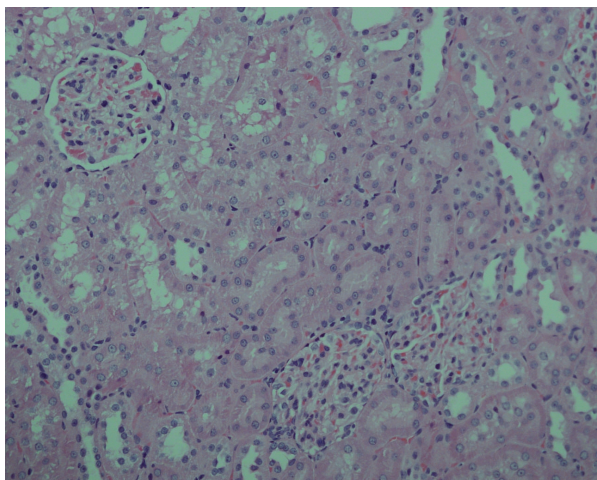

(c)

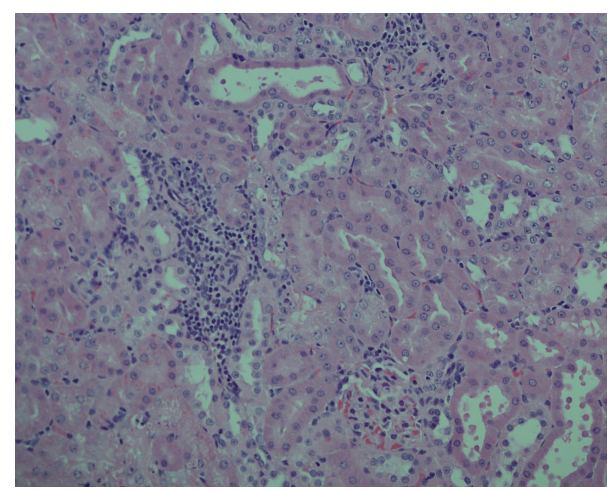

(b)

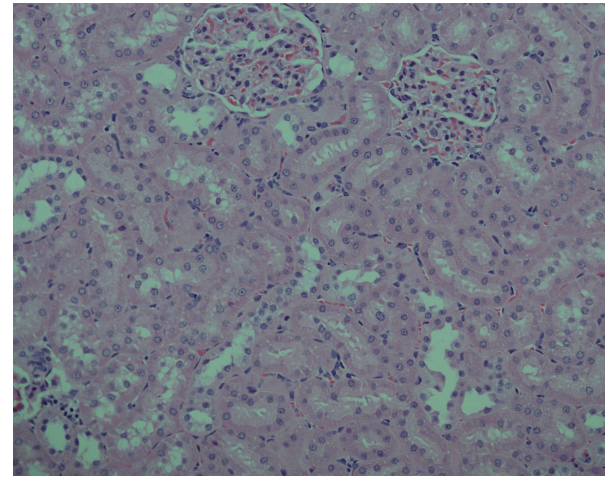

(d)

FIGURE 5: Representative photomicrographs of kidney sections from rats treated with BVEE and gentamicin (H\&E staining). Light microscopic examination ( $\times 20$ objective lens) of kidney tissue. (a) Normal kidney section; (b) effect of gentamicin on kidney tissue showing tubular degeneration, massive necrosis, and focal interstitial nephritis made up of lymphocytes and plasma cells, desquamation of renal tubule epithelium, and vacuolization; (c) effect of BVEE $250 \mathrm{mg} / \mathrm{kg}$, pretreatment showing absence of interstitial nephritis and improvement degree of renal tubule changes; (d) effect of BVEE $500 \mathrm{mg} / \mathrm{kg}$, pretreatment showing almost normal tubules, interstitial, and glomeruli.

activity. The observed antioxidant and renal protective effect is considered to be related to the phytoconstituents of beetroot such as betalains, terpenoids, sugars, phenolics, and ascorbic acid [10, 53-55]. All these constituents are known to reduce lipid peroxidation and prevent necrosis which protected the kidney tissue against the oxidative damage and nephrotoxic effect caused by GM treatment $[1,56,57]$.

Previous studies have reported that renal damage as a result of GM-induced tubular necrosis stimulates inflammatory events at the site of injury leading to enhance the migration of monocytes and macrophages to the site of tissue damage [16].

Myeloperoxidase (MPO) activity in the renal cortex is an index of neutrophil accumulation; therefore, an increase in MPO activity reflects the inflammatory infiltration to the site of tissue injury [58]. In the present study, GM treatment increased the levels of renal MPO activity, indicating neutrophil infiltration. BVEE treatment decreased renal neutrophils infiltration as evidenced by suppression of renal MPO activity and the improvement of histological features. The above findings indicate that BVEE has ability to ameliorate the GM-induced nephrotoxicity through its antiinflammatory effect. The role played by NO in nephrotoxicity is thought by some as controversial, although some workers have reported that it increased renal injury through its reactions with a superoxide radical and generation of a cytotoxic peroxynitrite [59]. GM treatment induced the nitric oxide level, therefore, increasing the inflammation leading to cellular damage the BVEE treatment significantly attenuate nitric oxide induced oxidative stress leading to reduction in inflammation as well as vasoconstriction of endothelial cells [60]. The activation and nuclear translocation of NF$\kappa \mathrm{B}$, in response to oxidative stress/nitrosative stress, are the key factors in the renal inflammatory process by regulating the gene expression of cytokines, chemokines, and adhesion molecules [17]. In this study, BVEE (250 and $500 \mathrm{mg} / \mathrm{kg}$ ) treatment along with GM significantly downregulates the renal nuclear protein expression of NF- $\kappa \mathrm{B}$ and NF- $\kappa \mathrm{B}-$ DNA binding activities as well as proinflammatory cytokines (TNF- $\alpha$ and IL-6) in dose dependent manner as compared to GM alone treated rats. Our findings corroborate those of earlier studies demonstrating that an increase in NF- $\kappa \mathrm{B}$ activation is also followed by an increase in the concentration of inflammatory cytokines like TNF- $\alpha$ and IL-6 $[17,18]$. Beet root extract is able to counteract proinflammatory cascades in peripheral blood mononuclear cells [2].

Apoptosis plays a key role in inflammatory process as well as various renal disease and drug induced nephrotoxicity 
[61-63]. The prolonged GM treatment may lead to acute renal failure with acute tubular necrosis [21, 64]. Caspasedependent apoptotic signaling has important role in GMinduced apoptotic renal damage. Caspase-3 can be activated by caspase-9 in the mitochondrial pathway [62]. Bax acts as a proapoptotic protein, whereas Bcl-2 acts as antiapoptotic protein. The $\mathrm{Bcl}-2$ proteins bind to the outer membrane of mitochondria and block cytochrome c activation [65].

In this contest, oxidative/nitrosative stress seems to play a major role in mitochondrial dysfunction which is an important early event in the intrinsic pathway of apoptosis [66]. GM administration upregulate the protein expression of cleaved caspase 3, Bax and down regulated Bcl-2 expression. This finding clearly shows that GM treatment triggers both apoptosis and inflammation leading necrosis in renal tissues. The BVEE treatment to GM treated rats significantly prevented renal tubular apoptosis/necrosis when compared to GM alone treated rats. Previous studies have shown that $\mathrm{NF}-\kappa \mathrm{B}$ activation promotes GM-induced apoptosis in rat renal tubular cells $[21,62]$. It is guessed that the proapoptotic character of NF- $\kappa \mathrm{B}$ might be due to its direct activation of apoptotic proteins such as caspase-3 or downregulation of antiapoptotic proteins such as $\mathrm{Bcl}-2$ [62]. Thus, the result of the present study revealed that BVEE attenuated NF- $\kappa \mathrm{B}$ activation; NF- $\kappa \mathrm{B}$ DNA binding and renal tubular apoptosis/necrosis associated with GM-induced renal damage. These findings are also in agreement with previously reported literature $[11,18,61,66,67]$. Histopathological examination of the GM treated kidney revealed the focal interstitial nephritis made up of lymphocytes and plasma cells with desquamation of renal tubule epithelium and vacuolization. Concomitant use of BVEE with GM ameliorated the renal toxicity induced by GM and resulted in the restoration of histological changes. The potent antioxidant activity of BVEE has been previously reported maybe due to presence of betacyanins including betanin and betanidin $[52,68]$.

In conclusion, the present study suggests that BVEE has a renal protective potential. The nephroprotective effect of BVEE against GM-induced renal toxicity may be ascribed to its antioxidant, antiapoptosis, and anti-inflammatory properties. These finding substantiate the use of beetroot extract in Arab traditional medicine for the treatment of renal disorders.

\section{Conflict of Interests}

The authors declare that they have no conflict of interests.

\section{Acknowledgment}

The authors extend their appreciation to the Deanship of Scientific Research at King Saud University for funding the work through the Research Group Project no. RGP-VPP-037.

\section{References}

[1] L. Váli, É. Stefanovits-Bányai, K. Szentmihályi et al., "Liverprotecting effects of table beet (Beta vulgaris var. rubra) during ischemia-reperfusion," Nutrition, vol. 23, no. 2, pp. 172-178, 2007.

[2] B. W. Christiana Winkler, K. Schroecksnadel, H. Schennach, and D. Fuchs, "In vitro effects of beet root juice on stimulated and unstimulated peripheral blood mononuclear cells," The American Journal of Biochemistry and Biotechnology, vol. 1, pp. 180-185, 2005.

[3] N. Sharma, B. S. Tanwer, and R. Vijayvergia, "Study of medicinal plants in Aravali regions of Rajasthan for treatment of kidney stone and urinary tract troubles," International Journal of PharmTech Research, vol. 3, no. 1, pp. 110-113, 2011.

[4] M. J. Ormsbee, J. Lox, and P. J. Arciero, "Beetroot juice and exercise performance," Nutrition and Dietary Supplements, vol. 5, pp. 27-35, 2013.

[5] M. J. Ormsbee, C. W. Bach, and D. A. Baur, "Pre-exercise nutrition: the role of macronutrients, modified starches and supplements on metabolism and endurance performance," Nutrients, vol. 6, no. 5, pp. 1782-1808, 2014.

[6] A. Singh, V. K. Garg, P. K. Sharma, and S. Gupta, "Wound healing activity of ethanolic extract of Beta vulgaris," Pharmacologyonline, vol. 1, pp. 1031-1038, 2011.

[7] P. Ninfali and D. Angelino, "Nutritional and functional potential of Beta vulgaris cicla and rubra," Fitoterapia, vol. 89, no. 1, pp. 188-199, 2013.

[8] S. G. V. Jain and P. K. Sharma, "Anti-inflammatory activity of aqueous extract of Beta vulgaris L," Journal of Basic and Clinical Pharmacy, vol. 2, pp. 83-86, 2011.

[9] R. Chakole, S. Zade, and M. Charde, "Antioxidant and antiinflammatory activity of ethanolic extract of Beta vulgaris Linn. roots," International Journal of Biomedical and Advance Research, vol. 2, pp. 124-130, 2011.

[10] T. S. Kujala, J. M. Loponen, K. D. Klika, and K. Pihlaja, "Phenolics and betacyanins in red beetroot (Beta vulgaris) root: distribution and effect of cold storage on the content of total phenolics and three individual compounds," Journal of Agricultural and Food Chemistry, vol. 48, no. 11, pp. 5338-5342, 2000.

[11] G. J. Kapadia, M. A. Azuine, G. S. Rao, T. Arai, A. Iida, and H. Tokuda, "Cytotoxic effect of the red beetroot (Beta vulgaris L.) extract compared to doxorubicin (adriamycin) in the human prostate (PC-3) and breast (MCF-7) cancer cell lines," AntiCancer Agents in Medicinal Chemistry, vol. 11, no. 3, pp. 280284, 2011.

[12] M. K. Reddy, R. L. Alexander-Lindo, and M. G. Nair, "Relative inhibition of lipid peroxidation, cyclooxygenase enzymes, and human tumor cell proliferation by natural food colors," Journal of Agricultural and Food Chemistry, vol. 53, no. 23, pp. 92689273, 2005.

[13] B. H. Ali, "Agents ameliorating or augmenting experimental gentamicin nephrotoxicity: some recent research," Food and Chemical Toxicology, vol. 41, no. 11, pp. 1447-1452, 2003.

[14] B. H. Ali, "Effect of dimethyl sulfoxide on gentamicin-induced nephrotoxicity in rats," Human and Experimental Toxicology, vol. 20, no. 4, pp. 199-203, 2001.

[15] C. Martinez-Salgado, F. J. Lopez-Hernandez, and J. M. LopezNovoa, "Glomerular nephrotoxicity of aminoglycosides," Toxicology and Applied Pharmacology, vol. 223, pp. 86-98, 2007.

[16] P. Balakumar, A. Rohilla, and A. Thangathirupathi, "Gentamicin-induced nephrotoxicity: do we have a promising therapeutic approach to blunt it?" Pharmacological Research, vol. 62, no. 3, pp. 179-186, 2010. 
[17] E. H. Bae, I. J. Kim, S. Y. Joo et al., "Renoprotective effects of the direct renin inhibitor aliskiren on gentamicin-induced nephrotoxicity in rats," Journal of the Renin-Angiotensin-Aldosterone System, 2013.

[18] S. Kalayarasan, P. N. Prabhu, N. Sriram, R. Manikandan, M. Arumugam, and G. Sudhandiran, "Diallyl sulfide enhances antioxidants and inhibits inflammation through the activation of Nrf2 against gentamicin-induced nephrotoxicity in Wistar rats," European Journal of Pharmacology, vol. 606, no. 1-3, pp. 162-171, 2009.

[19] I.-C. Lee, S.-H. Kim, S.-M. Lee et al., "Melatonin attenuates gentamicin-induced nephrotoxicity and oxidative stress in rats," Archives of Toxicology, vol. 86, no. 10, pp. 1527-1536, 2012.

[20] Y.-M. Sue, C.-F. Cheng, C.-C. Chang, Y. Chou, C.-H. Chen, and S.-H. Juan, "Antioxidation and anti-inflammation by haem oxygenase-1 contribute to protection by tetramethylpyrazine against gentamicin-induced apoptosis in murine renal tubular cells," Nephrology Dialysis Transplantation, vol. 24, no. 3, pp. 769-777, 2009.

[21] S. H. Juan, C. H. Chen, Y. H. Hsu et al., "Tetramethylpyrazine protects rat renal tubular cell apoptosis induced by gentamicin," Nephrology Dialysis Transplantation, vol. 22, no. 3, pp. 732-739, 2007.

[22] W. Brand-Williams, M. E. Cuvelier, and C. Berset, "Use of a free radical method to evaluate antioxidant activity," LWT_Food Science and Technology, vol. 28, no. 1, pp. 25-30, 1995.

[23] Organisation for Economic Co-operation and Development (OECD), Guidance Document for the Development of OECD Guidelines for Testing of Chemicals, OECD Environment, Health and Safety Publications, 1995.

[24] T. Jeyanthi and P. Subramanian, "Nephroprotective effect of withania somnifera: a dose-dependent study," Renal Failure, vol. 31, no. 9, pp. 814-821, 2009.

[25] N. Tietz, Textbook of Clinical Chemistry, WB Saunders, Philadelphia, Pa, USA, 1986.

[26] P. Fossati, L. Prencipe, and G. Berti, "Use of 3,5-dichloro2-hydroxybenzenesulfonic acid/4-aminophenazone chromogenic system in direct enzymic assay of uric acid in serum and urine," Clinical Chemistry, vol. 26, no. 2, pp. 227-231, 1980.

[27] P. Trinder, "Determination of blood glucose using an oxidaseperoxidase system with a non-carcinogenic chromogen," Journal of Clinical Pathology, vol. 22, no. 2, pp. 158-161, 1969.

[28] H. G. Utley, F. Bernheim, and P. Hochstein, "Effect of sulfhydryl reagents on peroxidation in microsomes," Archives of Biochemistry and Biophysics, vol. 118, no. 1, pp. 29-32, 1967.

[29] J. Sedlak and R. H. Lindsay, "Estimation of total, proteinbound, and nonprotein sulfhydryl groups in tissue with Ellman's reagent," Analytical Biochemistry, vol. 25, pp. 192-205, 1968.

[30] A. J. Krueger, J. J. Yang, T. A. Roy, D. J. Robbins, and C. R. Mackerer, "An automated myeloperoxidase assay," Clinical Chemistry, vol. 36, no. 1, p. 158, 1990.

[31] L. C. Green, D. A. Wagner, J. Glogowski, P. L. Skipper, J. S. Wishnok, and S. R. Tannenbaum, "Analysis of nitrate, nitrite, and $\left[{ }^{15} \mathrm{~N}\right]$ nitrate in biological fluids," Analytical Biochemistry, vol. 126, no. 1, pp. 131-138, 1982.

[32] H. Towbin, T. Staehelin, and J. Gordon, "Electrophoretic transfer of proteins from polyacrylamide gels to nitrocellulose sheets: Procedure and some applications," Proceedings of the National Academy of Sciences of the United States of America, vol. 76, no. 9, pp. 4350-4354, 1979.
[33] A. A. Shifow, K. V. Kumar, M. U. R. Naidu, and K. S. Ratnakar, "Melatonin, a pineal hormone with antioxidant property, protects against gentamicin-induced nephrotoxicity in rats," Nephron, vol. 85, no. 2, pp. 167-174, 2000.

[34] S. A. Lerner, B. A. Schmitt, R. Seligsohn, and G. J. Matz, "Comparative study of ototoxicity and nephrotoxicity in patients randomly assigned to treatment with amikacin or gentamicin," The American Journal of Medicine, vol. 80, no. 6, pp. 98-104, 1986.

[35] J. P. Morin, G. Viotte, A. Vandewalle, F. Van Hoof, P. Tulkens, and J. P. Fillastre, "Gentamicin-induced nephrotoxicity: a cell biology approach," Kidney International, vol. 18, no. 5, pp. 583590, 1980.

[36] J. Safa, H. Argani, B. Bastani et al., "Protective effect of grape seed extract on gentamicin-induced acute kidney injury," Iranian Journal of Kidney Diseases, vol. 4, no. 4, pp. 285-291, 2010.

[37] A. Jain and A. K. Singhai, "Effect of Momordica dioica Roxb on gentamicin model of acute renal failure," Natural Product Research, vol. 24, no. 15, pp. 1379-1389, 2010.

[38] A. Whelton and K. Solez, "Pathophysiologic mechanisms in aminoglycoside nephrotoxicity," The Journal of Clinical Pharmacology, vol. 23, no. 10, pp. 453-460, 1983.

[39] S. O. Adewole, A. A. Salako, O. W. Doherty, and T. Naicker, "Effect of melatonin on carbon tetrachloride-induced kidney injury in Wistar rats," African Journal of Biomedical Research, vol. 10, pp. 153-164, 2007.

[40] M. R. Khan, I. Badar, and A. Siddiquah, "Prevention of hepatorenal toxicity with Sonchus asper in gentamicin treated rats," BMC Complementary and Alternative Medicine, vol. 11, article 113, 2011.

[41] N. Ullah, M. A. Khan, T. Khan, and W. Ahmad, "Cymbopogon citratus protects against the renal injury induced by toxic doses of aminoglycosides in rabbits," Indian Journal of Pharmaceutical Sciences, vol. 75, no. 2, pp. 241-246, 2013.

[42] M. Reiter, K. Rupp, P. Baumeister, S. Zieger, and U. Harreus, "Antioxidant effects of quercetin and coenzyme Q10 in mini organ cultures of human nasal mucosa cells," Anticancer Research, vol. 29, no. 1, pp. 33-39, 2009.

[43] W. H. El-Tantawy, S. Abdel-Halim Mohamed, and E. N. Abd Al Haleem, "Evaluation of biochemical effects of Casuarina equisetifolia extract on gentamicin-induced nephrotoxicity and oxidative stress in rats. Phytochemical analysis," Journal of Clinical Biochemistry and Nutrition, vol. 53, no. 3, pp. 158-165, 2013.

[44] E. Pigeolet, P. Corbisier, A. Houbion et al., "Glutathione peroxidase, superoxide dismutase, and catalase inactivation by peroxides and oxygen derived free radicals," Mechanisms of Ageing and Development, vol. 51, no. 3, pp. 283-297, 1990.

[45] B. Halliwell and J. M. Gutteridge, "Oxygen toxicity, oxygen radicals, transition metals and disease," Biochemical Journal, vol. 219, no. 1, pp. 1-14, 1984.

[46] A. A. J. Nayagam, S. Manokaran, and N. Sudhakar, "Hepatoprotective efficacy of Tricholepis radicans DC. against CC14 induced liver toxicity in albino rats," Journal of Pharmacy Research, vol. 4, pp. 1073-1075, 2011.

[47] B. Nitha and K. K. Janardhanan, "Aqueous-ethanolic extract of morel mushroom mycelium Morchella esculenta, protects cisplatin and gentamicin induced nephrotoxicity in mice," Food and Chemical Toxicology, vol. 46, no. 9, pp. 3193-3199, 2008. 
[48] T. A. Ajith, S. Usha, and V. Nivitha, "Ascorbic acid and $\alpha$ tocopherol protect anticancer drug cisplatin induced nephrotoxicity in mice: a comparative study," Clinica Chimica Acta, vol. 375, no. 1-2, pp. 82-86, 2007.

[49] O. A. Badary, S. Abdel-Maksoud, W. A. Ahmed, and G. H. Owieda, "Naringenin attenuates cisplatin nephrotoxicity in rats," Life Sciences, vol. 76, no. 18, pp. 2125-2135, 2005.

[50] T. P. A. Devasagayam, J. C. Tilak, K. K. Boloor, K. S. Sane, S. S. Ghaskadbi, and R. D. Lele, "Free radicals and antioxidants in human health: current status and future prospects," Journal of Association of Physicians of India, vol. 52, pp. 794-804, 2004.

[51] M. Kujawska, E. Ignatowicz, M. Murias, M. Ewertowska, K. Mikołajczyk, and J. Jodynis-Liebert, "Protective effect of red beetroot against carbon tetrachloride- and N-nitrosodiethylamine-induced oxidative stress in rats," Journal of Agricultural and Food Chemistry, vol. 57, no. 6, pp. 2570-2575, 2009.

[52] C. H. Lee, M. Wettasinghe, B. W. Bolling, L. L. Ji, and K. L. Parkin, "Betalains, phase II enzyme-inducing components from red beetroot (Beta vulgaris L.) extracts," Nutrition and Cancer, vol. 53, no. 1, pp. 91-103, 2005.

[53] M. Wettasinghe, B. Bolling, L. Plhak, H. Xiao, and K. Parkin, "Phase II enzyme-inducing and antioxidant activities of beetroot (Beta vulgaris L.) extracts from phenotypes of different pigmentation," Journal of Agricultural and Food Chemistry, vol. 50, no. 23, pp. 6704-6709, 2002.

[54] R. Kazimierczak, E. Hallmann, J. Lipowski et al., "Beetroot (Beta vulgaris L.) and naturally fermented beetroot juices from organic and conventional production: metabolomics, antioxidant levels and anticancer activity," Journal of the Science of Food and Agriculture, vol. 94, no. 13, pp. 2618-2629, 2014.

[55] V. Krajka-Kuźniak, J. Paluszczak, H. Szaefer, and W. BaerDubowska, "Betanin, a beetroot component, induces nuclear factor erythroid-2-related factor 2-mediated expression of detoxifying/antioxidant enzymes in human liver cell lines," British Journal of Nutrition, vol. 110, no. 12, pp. 2138-2149, 2013.

[56] C. S. Yang, J. M. Landau, M.-T. Huang, and H. L. Newmark, "Inhibition of carcinogenesis by dietary polyphenolic compounds," Annual Review of Nutrition, vol. 21, pp. 381-406, 2001.

[57] C. A. Rice-Evans, N. J. Miller, and G. Paganga, "Structureantioxidant activity relationships of flavonoids and phenolic acids," Free Radical Biology and Medicine, vol. 20, no. 7, pp. 933956, 1996.

[58] X. Guo, Q. Meng, Q. Liu et al., "JBP485 improves gentamicininduced acute renal failure by regulating the expression and function of Oatl and Oat3 in rats," Toxicology and Applied Pharmacology, vol. 271, no. 2, pp. 285-295, 2013.

[59] J. S. Christo, A. M. Rodrigues, M. G. Mouro et al., "Nitric oxide (NO) is associated with gentamicin (GENTA) nephrotoxicity and the renal function recovery after suspension of GENTA treatment in rats," Nitric Oxide, vol. 24, no. 2, pp. 77-83, 2011.

[60] R. Ghaznavi and M. Kadkhodaee, "Comparative effects of selective and non-selective nitric oxide synthase inhibition in gentamicin-induced rat nephrotoxicity," Archives of Toxicology, vol. 81, no. 6, pp. 453-457, 2007.

[61] B. D. Sahu, S. Tatireddy, M. Koneru et al., "Naringin ameliorates gentamicin-induced nephrotoxicity and associated mitochondrial dysfunction, apoptosis and inflammation in rats: possible mechanism of nephroprotection," Toxicology and Applied Pharmacology, vol. 277, no. 1, pp. 8-20, 2014.

[62] Y.-C. Chen, C.-H. Chen, Y.-H. Hsu et al., "Leptin reduces gentamicin-induced apoptosis in rat renal tubular cells via the
PI3K-Akt signaling pathway," European Journal of Pharmacology, vol. 658, no. 2-3, pp. 213-218, 2011.

[63] H. Servais, P. van der Smissen, G. Thirion et al., "Gentamicininduced apoptosis in LLC-PK1 cells: involvement of lysosomes and mitochondria," Toxicology and Applied Pharmacology, vol. 206, no. 3, pp. 321-333, 2005.

[64] H. Khalili, S. Bairami, and M. Kargar, "Antibiotics induced acute kidney injury: incidence, risk factors, onset time and outcome," Acta Medica Iranica, vol. 51, no. 12, pp. 871-878, 2013.

[65] Y. Kalkan, K. A. Kapakin, A. Kara et al., "Protective effect of Panax ginseng against serum biochemical changes and apoptosis in kidney of rats treated with gentamicin sulphate," Journal of Molecular Histology, vol. 43, no. 5, pp. 603-613, 2012.

[66] A. I. Morales, D. Detaille, M. Prieto et al., "Metformin prevents experimental gentamicin-induced nephropathyby a mitochondria-dependent pathway," Kidney International, vol. 77, no. 10, pp. 861-869, 2010.

[67] P. Jia, J. Teng, J. Zou et al., "Intermittent exposure to xenon protects against gentamicin-induced nephrotoxicity," PLOS ONE, vol. 8, no. 5, Article ID e64329, 2013.

[68] J. Kanner, S. Harel, and R. Granit, "Betalains-a new class of dietary cationized antioxidants," Journal of Agricultural and Food Chemistry, vol. 49, no. 11, pp. 5178-5185, 2001. 


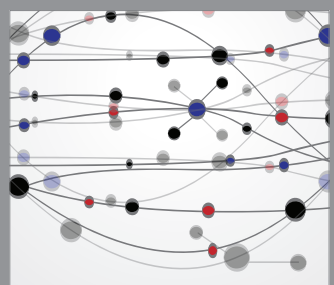

The Scientific World Journal
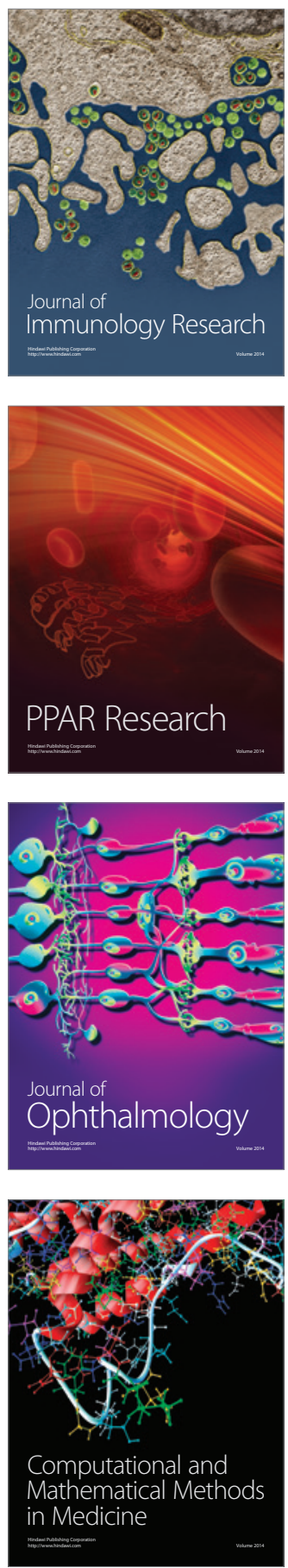

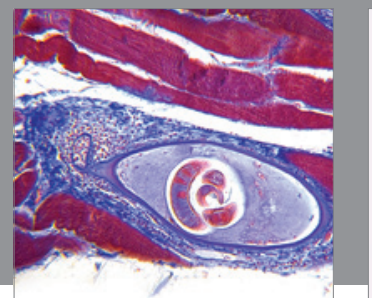

Gastroenterology

Research and Practice
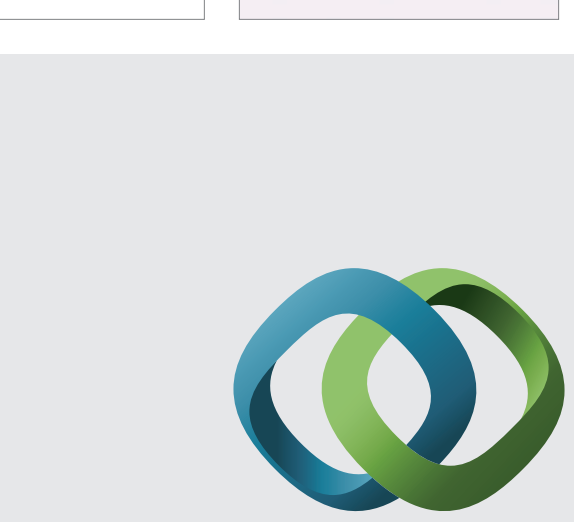

\section{Hindawi}

Submit your manuscripts at

http://www.hindawi.com
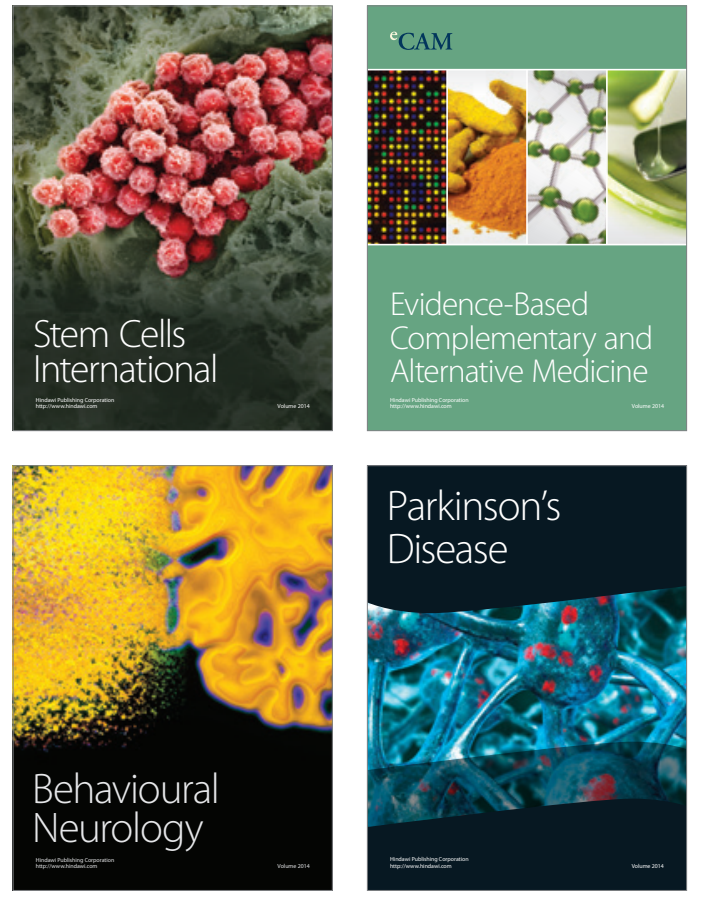
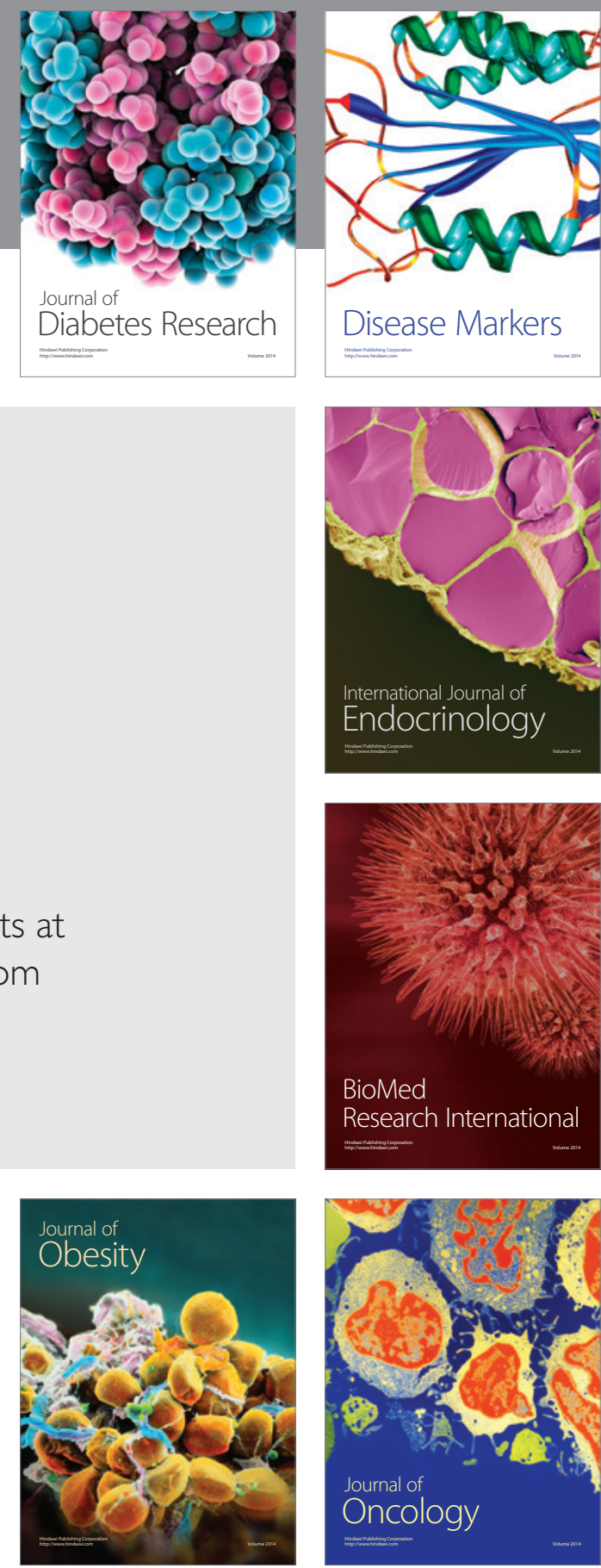

Disease Markers
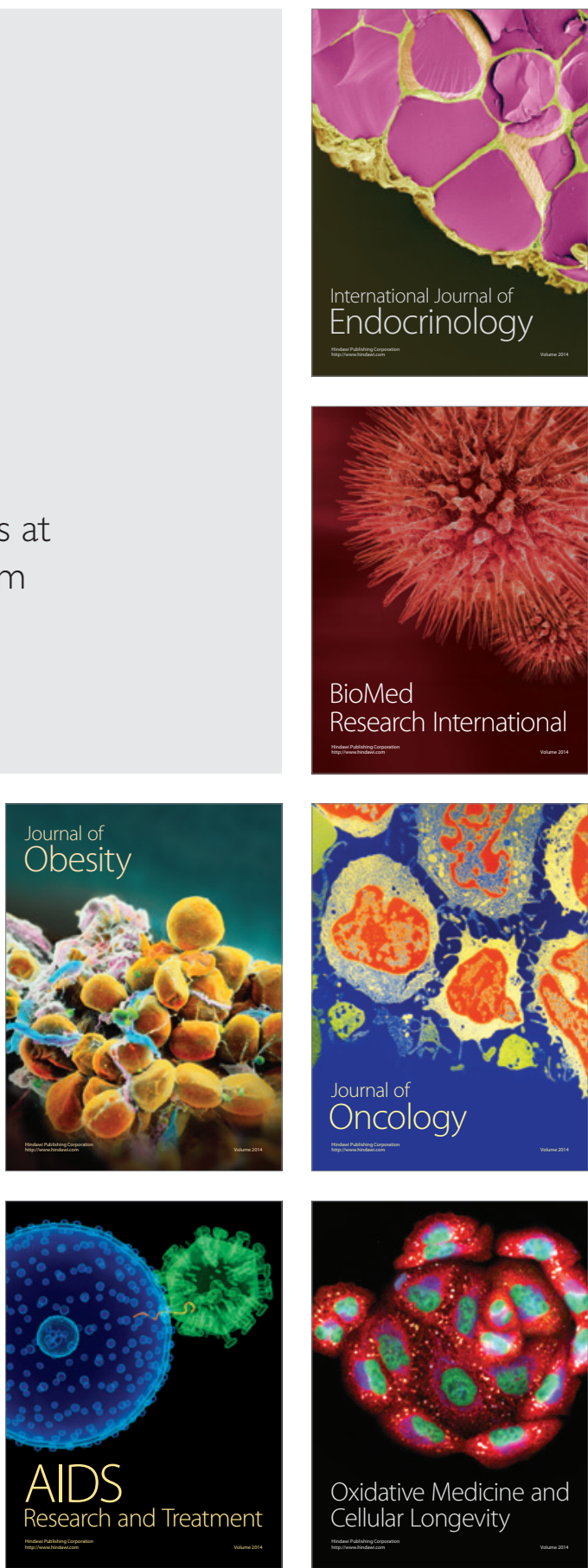